\title{
Italo Testa
}

\section{How does recognition emerge from nature? \\ The genesis of consciousness in Hegel's Jena writings}

(forthcoming in "Critical Horizons", 2012)

It is widely assumed in recent literature that the Hegelian Spirit - the social structure of the historical world of individual agents and institutions - is constituted through recognition (Anerkennung), i.e. through processes of reciprocal interaction ${ }^{1}$. Thus recognition is understood as the master concept of spirit and its basic structure: an idea that is also shared by many thinkers who do not dwell on Hegelian assumptions but nevertheless understand the social world in recognitive terms ${ }^{2}$. Furthermore, recognition is normally assumed to be a bootstrapping process, that is, a self-positing and self-justifying normative social phenomenon, intelligible within and of itself and independently of anything external to it $^{3}$. Thus right from the very beginning recognition is situated within the social and historical world of agents. As a consequence, an image of spirit arises as something whose genesis and constitution can be investigated independently from natural processes. Here normative recognition and spirit tend to be conceived of as identical, and a sort of circularity seems to arise: if spirit is explicated through recognition, and recognition is identical with the basic, normative structure of the social and historical sphere, then it is as if spirit were explicated through spirit. A further objection arises when one considers that such a picture tends to support a very thin image of sociality as something entirely normative. A further reason for

1 See for example: A. Honneth, The Struggle for Recognition: The Moral Grammar of Social Conflicts, J. Anderson (trans.) (Cambridge: Polity Press, 1995); T. Pinkard, Hegel's Phenomenology. The Sociality of Reason (Cambridge: Cambridge University Press, 1994).

2 On the importance of the notion of recognition for the social and political philosophy of the last decades see: N. Fraser, "From Redistribution to Recognition? Dilemmas of Justice in a 'Postsocialist Age"', New Left Review, 212 (July-August 1995), 68-93; Multiculturalism and the 'Politics of Recognition, Ch. Taylor and A. Guttmann (eds), (Princeton: Princeton University Press, 1992).

3 See for example R. Pippin, "Hegelian Sociality: Recognitive Status", in his Hegel's Practical Philosophy. Rational Agency as Practical Life, 202 (Cambridge: Cambridge University Press, 2008): "Hegel's theory of recognition has turned out to be a theory of practical rationality of a radically 'boot-strapping' (internally self-determining and internally selfjustifyng sort)". 
not being satisfied with this as constituting the whole story is the fact that such a picture tends to forget how much the notion of spirit is entwined with natural processes in Hegel's texts. And I think the most significant way to prove this is to draw attention explicitly to the neglected fact that in Hegel even recognition emerges out of nature, thus somehow preceding the spiritual sphere, and is not totally identical with it. Along these lines, I will propose a reconstruction of some fragments of Hegel's Jena manuscripts, which I assume to be relevant not only for exegetical purposes, but also to show that some as yet unacknowledged Hegelian insights could play a significant role in contemporary debates concerning recognition: if spirit is constituted through recognition, then the fact that recognition somehow depends on nature will have deep consequences on how we are to conceive the genesis and the structure of the social and historical world.

In order to regain these Hegelian insights, I will reconstruct some aspects of the natural genesis of spiritual consciousness in Hegel's Jena writings. This reconstruction will aim to highlight the genesis and the structure of the fundamental capacities that are presupposed by recognitive interaction. The following thesis will be defended: Hegel in his Jena writings laid the foundations for a Naturphilosophie of recognition, sketching a sort of natural history of the evolution of the recognitive relation to oneself; a relation that starts from an organic self, endowed with communicative capacities that enable it to interact with its environment and other selves.

First of all, I will follow the path that leads from the 1801 Differenzschrift to the lessons on the philosophy of spirit given by Hegel during the 1803 summer semester and the 1803-4 winter semester ${ }^{4}$. The reconstruction of this path is articulated in five steps. In the first step I will deal with the problem of natural recognition as emerging from sexual differentiation and interaction. Secondly, I will analyze the Hegelian conception of the proto-intentional organic self and of its proprioceptive and communicative structure. Thirdly, I will discuss the practical structure of "appetite (Begierde)" - understood as a form of practical intentionality - and of the forms of conflictive, proto-recognitive interactions arising from it. Fourthly, I will treat the question of the animal voice understood as an expressive act that manifests the natural being's longing to see its own individuality recognized. Fifthly, I will

These fragments, published for the first time by J. Hoffmeister under the title Realphilosophie (see G.W.F. Hegel, Jenenser Realphilosophie, I. Die Vorlesungen von 1803/4. Aus dem Manuskript hrsg. v. J. Hoffmeister [Leipzig: 1932], were later republished in the critical edition of the Hegel-Archiv: see G.W.F. Hegel, Jenaer Systementwürfe I. Das System der spekulativen Philosophie, K. Düsing \& H. Kimmerle (eds), in Gesammelte Werke, vol. 6, hereafter GW6 [Hamburg: Meiner, 1975]. 
analyze the form of recognition that manifests itself with procreation and that constitutes the natural root of reason as a first form of objectivation. Finally, after having sketched the defective sides of the natural forms of recognition, I will argue that the forms of reflexive consciousness that develop in the realm of spirit presuppose the pre-reflexive recognitive consciousness and are more complex reorganizations of its fundamental structure.

\section{Sexual differentiation and natural individuation}

The philosophy of nature canvassed in the fragments 1-15 of the 1803-4 lessons deals with a "system of the earth", mechanism, chemism, physics and the organic world. Fragment 15, in particular, also contains the beginning of the philosophy of spirit. Here what I am going to name "natural recognition" plays a crucial role in the move from the philosophy of nature to the philosophy of spirit, in a way that further develops the intuition (which had already emerged in the Frankfurt period) according to which consciousness constitutes itself as a form of organization of the living being.

The notion of organism is essential here as it is the notion around which is articulated the natural development of the forms of consciousness - and in particular of its recognitive structures - that will be the medium, the "middle term (Mitte)" of spirit ${ }^{5}$. Already in the Differenzschft Hegel had introduced "recognition (Anerkennung)" as a natural phenomenon that concerns the "genus (Gattung)" and the polarity of sexes 6 . Sexual difference of

On the Hegelian notion of “organism” see: O. Breidbach, Das Organische in Hegels Denken. Studien zur Naturphilosophie und Biologie um 1800 (Würzburg: Königshausen \& Neumann, 1982); D. von Engelhardt, "Die biologische Wissenschaften in Hegels Naturphilosophie”, in Hegels Philosophie der Natur, R.-P. Horstmann \& M.J. Petry (eds), 121-137 (Stuttgart Bad Cannstatt: Frommann-Holzboog, 1986); L. Illetterati, "Vita e organismo nella filosofia della natura di Hegel", in Filosofia e scienze filosofiche nell"Enciclopedia' hegeliana del 1817, F. Chiereghin (ed), 327-427 (Trento: Verifiche, 1995). For an analysis of this subject in Hegel's Jena writings see: H. Kimmerle, "Hegels Naturphilosophie in Jena”, in Hegel in Jena, D. Henrich \& K. Düsing (eds), 207-215 (Bonn: Bouvier, 1980); O. Braidbach, "Das Organische in Hegels Jenaer Naturphilosophie", in Hegels Jenaer Naturphilosophie, K. Vieweg (ed), 309-318 (München: Fink, 1998). On the 1803-4 philosophy of nature see also: W. Neuser, "Hegels Naturphilosophie der Jenaer Zeit und ihre Bedeutung für die Systemkonzeption”, in Die Eigenbedeutung der Jenaer Systemkonzeptionen Hegels, H. Kimmerle (ed), 89-98 (Berlin: Akademie Verlag, 2004); B. Tuschling, "Natur und Geist im Systementwurf I", in Hegels Jenaer Naturphilosophie, 71-83; E. Renault, "Les transformations de l'idée de Naturphilosophie à Ièna (1801-6)", paper given at the conference « Hegel et les Esquisses de système d'Iéna », Ecole Normale Supérieure de Lyon (November 13, 2009), forthcoming in the conference procedings.

$6 \quad$ G.W.F.Hegel, Differenz, in Kritische Schriften, H. Buchner \& O. Pöggeler (eds), in Gesammelte Werke, vol. 4, 73 [Hamburg: Meiner, 1968], published in English as The difference between Fichte's and Schelling's system of philosophy, H. 
organisms was considered as the condition of manifestation of recognitive phenomena properly speaking. In the Differenzschrift recognition was thus understood as a natural phenomenon that manifests itself as a mechanism of coordination between natural interactions aimed at sexual reproduction ${ }^{7}$. And this offers us a key to reconstruct the problem of natural recognition within the more articulated conception of the genesis of consciousness developed by Hegel in the 1803-4 lessons.

In the analysis of organism in the 1803-4 lessons the animal organism properly said is a new level of self-organization of the living being: a level that cannot be adequately grasped solely with the notions that apply to physical and chemical processes ${ }^{8}$. As such, the animal organism is a "living unity (eine lebendige Einheit)" as to moments of its own process of differentiation and organization. The organism that preserves itself is thus determined and identifiable as a "singularity (Einzelnheit)" that is understood as a "numerical unit (ein numerisches Ein)", i.e. a quantitative determination ${ }^{10}$.

In the positing of the individuated structure of the living organism, the notion of Gattung plays an important role. Organic individuality is defined as the "absolute middle term (absolute Mitte)" between two processes: the cycle through which the singular organism preserves and individuates itself, and the cycle through which the Gattung - the universal moment - endures through sexual reproduction of individuals. The natural process is thus the beginning of a process of individuation through universalization. In this sense Hegel writes:

The idea of organic individuality is genus, universality; it is infinitely an other to itself and in this otherness [is] itself, exists in the division of the sexes, each of which is the entire idea,

S. Harris \& W. Cerf [trans], 168 [Albany: Suny, 1977].

7 For a more detailed analysis of the Differenzschrift, and more generally for a global reconstruction of the notion of "natural recognition" in the Jena writings, see I. Testa, La natura del riconoscimento. Riconoscimento naturale e autocoscienza sociale in Hegel, 177 ff. (Milano: Mimesis, 2010).

$8 \quad$ GW6, Fragment 7, 58.

9 GW6, Fragment 10, 189.

10 GW6, Fragment 15, 267, published in English in G.W.F. Hegel, System of Ethical Life (1802-3) and First Philosophy of Spirit (Part III of the System of Speculative Philosophy 1803/04), H.S. Harris and T.M. Know (eds and trans), 206 (Albany: Suny, 1979). On the physical and chemical antecedents of the individuality of the organism, and on its non reducibility to the previous levels, see U. Schlösser, "Natur und Geist oder Leib und Seele? Eine Perspektive auf Hegels Systemansatz in den "Jenaer Systementwürfen I”, in Die Eigenbedeutung der Jenaer Systemkonzeptionen Hegels, 117-133. See also F. Rühling, “Anorganische Natur als Subjekt”, in Hegels Jenaer Naturphilosophie, 359-366. 
but such that it, relating to itself as to an other, intuits itself in otherness as itself and supersedes this opposition. ${ }^{11}$

Natural individuation is deeply linked to sexual differentiation and intercourse. It is through the proto-sociality of sexual intercourse that animal organisms begin to manifest themselves as individuals and to appreciate the individuality of other organisms. Intercourse presupposes that mates recognize themselves as belonging to the same genus or species, ${ }^{12}$ and simultaneously that they recognize their sexual difference and the other's individuality. At the same time, the recognitive structure of "relating to itself as to an other" is here rooted at the organic level: the very possibility of relating to itself - the form of pre-reflexive selfrelation that the natural organism manifests at this level - is linked to the possibility of intuiting oneself in another organism of the same species. It is not by chance that Hegel names sexual differentiation a "doubling (Verdopplung)"13, employing the word that in the Frankfurt writings had been used to refer to intersubjectivity understood as doubling of life. Furthermore, designating organic individuality as a "middle term (Mitte)", an "essence (Wesen)" and a "movement (Bewegung)", again Hegel finds at the organic level some aspects that will be constitutive of the dynamics of consciousness.

Organic individuality is already an individuality whose capacity of self-relation is mediated by the relation to the other. Hegel finds here again at the organic level the typical logical notion of the unity of self-relation and relation to the other that had already been situated, in the Frankfurt writings, within the living process, and that will characterize the structure of consciousness in the 1803-4 fragments that we will consider. The "other" to which the individual is always related, inasmuch as it relates to itself, is the universal other of the Gattung. This universal, immediately present in the individual, is what the individual has to become through its own process of natural development and social individuation.

The Gattung, the universal moment, is present as an "ideal" moment within the organism. At the same time, the Gattung in some sense exists, through organic differentiation and the division of sexes, in the other organisms of the same species with whom the individual interacts. This distinction of sexes, that in the vegetal organism is still unstable, gives rise in

11 "Die Idee der organischen Individualität ist Gattung, Allgemeinheit; sie ist sich unendlich ein anderes und in diesem Anderssein sie selbst, existiert in der Trennung der Geschlechter, deren jedes die ganze Idee ist, aber die, sich auf sich selbst als auf ein Äußeres beziehend, sich [im] Anderssein als sich selbst anschaut und diesen Gegensatz aufhebend" (GW6, Fragment 10, 185-186).

12 From here on Hegel's Gattung (genus), used in biological contexts, will be generally translated as 'species'.

13 GW6, Fragment 13, GW6, 240. 
the animal organism to a proper form of determined differentiation. While the vegetal organism is a form of life deprived of selfhood, with the animal organism a process of individuation begins and a first form of "natural self" comes into being. Still, in animal life the Gattung is "ideal" insofar as it is a living universal that does not exist as such, or for itself. Unlike in the spiritual domain - where the universal manifests itself in the institutional structures through which individuals are socialized - the natural process of individuation through social universalization exists only through the infinite division and differentiation of individuals and thus as their "contact (Berührung)" through intercourse.

\section{The organic self: proprioception and communication}

The second step of my reconstruction of the 1803-4 lessons concerns the process of development of an organic self through proprioception and communication.

The animal organism, according to Hegel, is a differentiated system of processes related to specific organs and functions. The development and the functional differentiation of the organism is in fact the process through which the singular being begins to individuate itself, a process that culminates in sexual differentiation. The vital movement of the organism is described by Hegel as an ensemble of three processes: 1) an internal growth process; 2) a process of preservation through assimilation of the external inorganic and organic nature; and finally 3) the "system of the senses (System der Sinne)", which unifies internal and external processes. The relation between these systems is a living unity - according to a non-reductionist conception of the relation between physical, chemical and biological levels: upper, biological levels have lower, physical and chemical levels as their conditions, and the latter, reciprocally, can be preserved only through the permanence of the selforganization of the former.

The "system of the senses" is properly the movement where the universalization of the individual begins ("the universal becoming of the individual as such" ${ }^{14}$ ): i.e. the process through which the universal of Gattung begins to be internalized. It is important to note that Hegel describes the "system of the senses" also as a "theoretical process", that is as the process of development of the cognitive structures of the organism. In the 1803-4 lessons this process is described as a sort of cerebralization: the brain is the differentiated part of the

14 “das Allgemeinwerden des Individuums als eines solchen" (GW6, Fragment 15, 247). 
nervous system that unifies the sentient systems in which the nerves differentiate themselves. As such, the brain develops as something "universally communicating (das allgemein Mitteilende)"15. On one hand such a communicative function is an internal system, insofar as it coordinates different sentient systems of the organism. The developing of the internal communicative function between sentient systems through the brain makes it possible for the overall movement of the organism to return to itself and for it to "feel" its own feeling. On the other hand, the communicative function of the internal sentient system through the brain develops into an external system of perception and communicative coordination with the other organisms that inhabit its environment. The internal self-relation of the sensation as a feeling of oneself - a form of proprioception - is possible only insofar as the sentient organism meets something external in which it feels its own feeling. Thereby external communication between different organisms and internal communication between sentient systems are tightly interrelated. In this light sexual interaction is again paradigmatic for Hegel insofar as it can be characterized in cognitive terms as a form of mutual perception through which living beings communicate and learn to recognize themselves as different sentient individuals of the same species. Hegel writes:

As this identity of singularity and universality of being - in its being superseded - it becomes the organic self, for the sentient animal its whole sensitivity becomes something external; what it relates itself to is itself as sentient, or for the sentient animal the ideality of sensation turns immediately into sexual difference. ${ }^{16}$

Proprioception is self-feeling exerted by an "organic self (organisches Selbst)". This organic self is the primitive intentional structure, the proto-intentionality which constitutes the precursor of that form of natural self which Hegel attributes to human beings and names "character (Charakter)" "17. "Sensation (Empfindung)" is hereafter not conceived by Hegel as a simple state of the subject but rather as the activity of a natural self that relates to itself. The recognitive capacity finds here an organic support and is defined at the same time in terms of communication. In fact, the brain makes it possible for the organic self to relate to itself only insofar as it is "communicating": that is to say, it exerts a sentient, internal

15 GW6, Fragment 13, 235.

16 "als diese Identität der Einzelheit und Allgemeinheit des Seins in seinem Aufgehobensein wird es das Organische Selbst, und für das empfindende Animalische wird sein ganzes Empfinden ein Äußeres; das, worauf es sich bezieht, ist es selbst als Empfindendes, oder die Idealität der Empfindung wandelt sich dem Empfindenden unmittelbar in Geschlechtsdifferenz um. " (ibid.).

17 GW6, Fragment 15, GW6, 260n1. 
communicative coordinating function between particular sensations within the organism. Furthermore, it also exerts (outside the organism) an external communicative function of perceptive and social coordination with the environment and other organisms. Hegel writes:

The theoretical system as relation between sexes reflects itself just as little in itself; it is only the individual's relation to another ${ }^{18}$.

It is important to note that the development of the "theoretical system", that is of the cognitive structures of the sentient organism, is analyzed by Hegel as something that is integrated within the course of action of a corporeal individual that is confronted with the environment and with other living individuals to which it attributes a practical value. That's why the "theoretical system" of the senses develops in Hegel's analysis into the relation between sexes, that is into a form of practical interaction.

\section{The practical relation of Begierde and conflict}

The third step of this reconstruction concerns the practical structure of "appetite (Begierde)" and the conflictive interaction which are the natural roots of the struggle for recognition. As we have seen, Hegel analyses the system of senses as a "theoretical process": this means that here cognitive capacities are developing, even if they have not yet become conceptual capacities. But Hegel also attributes a practical value to these cognitive structures. In fact, the sentient process encompasses both the self-preserving cycle of nutrition and the reproductive cycle of the Gattung ${ }^{19}$. The "theoretical" process of the animal was a protointentional self-relation with the inorganic and organic environments that are the objects of its sensations. The practical side of this process is first of all its "annihilating" activity. The animal feels the object as something to be assimilated and destroyed.

This practical relation to the object that has to be destroyed, being cognitively mediated by sensation, is further characterized as Begierde. The organism preserves itself through this annihilating relation and consequently lives in a state of "tension (Spannung)", since it is both the subject of an annihilating activity and the object of the annihilating activity exerted

18 "das theoretische System als Geschlechtsverhältnis reflektiert sich ebensowenig in sich selbst; es ist nur die Beziehung des Individuums auf ein andres. "(GW6, Fragment 15, 247). 
by the inorganic and organic environments which surround it. Once again Begierde is not only an appetitive movement towards an external object to be obtained, but also a form of cognitive and practical self-relation. The animal, living in a condition of fear, relates to itself with a feeling of defectiveness. This self-relation is characterized as a form of "negativity" which takes different shapes: hunger, thirst, in particular. Furthermore, the tension proper to Begierde interpenetrates also the other cycle of the organism, i.e. the reproductive cycle (the Spannung of sexual appetite). In fact, the universal of the Gattung is immediately present in the individual as something in which the individual is negated: the species perpetuates itself through the individual. On the one hand it is through sexual intercourse and reproduction that animal organisms first come to manifest their individuality, since sexual intercourse requires for individuals to let themselves be recognized as such by their mates. On the other hand, once the reproduction cycle is completed, the individual has exhausted its function is destined to death - and is reduced to an instrument of the reproduction of the species. The life of the species is just the cycle of reproduction and annihilation of the individuals. In the animal organism endowed with a theoretical system, the annihilating movement is mediated by its sensation in the form of hunger, thirst, sexual appetite. This means that the feeling of defectiveness and fear through which the animal relates to itself manifests the fragile condition of its natural individuality.

The relation between the individual and the Gattung - which exists only in the form of another organism of the same species - is itself an appetitive relation: a sensation of the individual's own negativity which manifests itself by a tension to delay and oppose the annihilating activity exerted by the Gattung and the surrounding environment. This is expressed more specifically in the fact that organisms establish reciprocal negative, practical appetitive relations by mutually reducing themselves to objects of exploitation. This negative, social relation of annihilation encompasses both the relation between the organisms of the same species and the reproductive cycle ${ }^{20}$, in which appetite presents itself as a tendency to realize its own organic self in the sentient individual. This tendency is on the one hand a reaction to the annihilating activity of the Gattung, on the other hand an attempt, destined to fail, to preserve its own individuality and to see it recognized as such. Here is to be found an animal root of the mechanism of the struggle for recognition, which, in fact, can be characterized as the perpetual return of the state of nature within historical

20 On the presence of the motif of the struggle for life and death in animal sexuality see H.S. Harris, Hegel's Development II. Night Thoughts (Jena 1801-1806) 293n (Oxford: Clarendon Press, 1983). 
relations: the struggle for recognition thus spiritualizes this mechanism of natural confliction without ever suppressing it.

\section{Animal voice and individuality's expressive recognition}

We are now at the point where we see emerge the expressive role of animal voice and its relation to the natural longing to see its own individuality recognized. Another important moment of the natural genesis of cognitive and practical structures of recognition is the Hegelian analysis of the function of the "voice (Stimme)". The sentient process returns to itself as "voice". We have already seen that the proprioception of the organism is linked to theinternal and external communicative function. The voice is the most articulated modality of expression at the disposal of the organism in which internal and external communication come together, insofar as the voice coordinates the social interactions of the individual both pacific and conflictual - with other organisms.

Here Hegel introduces the voice as the culmination of the universalizing process of the sentient self-relation of the "theoretical system". This self-relation presents itself in its structural form as universal sense, "feeling (Gefühl)" - one could say a form of self-feeling. A feeling that relates to itself both in its generality and in the particularity of the five senses, and whose external manifestation is the "face (Gesicht)". The connection between the gestural attitude of the body and the expressiveness of the face manifests itself here already at the natural level. In the System der Sittlichkeit this allowed Hegel to reconstruct the genesis of the forms of linguistic communication as different layers of the systems of expressive recognition, starting from the simple forms of face recognition ${ }^{21}$.

One can better understand the nexus between voice and self-relation if we consider what Hegel wrote about the voice as "sense of sound (Sinn des Tones)". The sensation differentiated into the multiplicity of senses returns to itself in the voice as to a whole and manifests itself in the feeling of its own individuality. The expressive function of the voice consists thus in bringing individuality into light. In the 1803-4 lessons Hegel writes:

The sense of sound as such is this simple infinity, in which the animal communicates absolutely that it is universal sense, opposed to every particularity of this sense, and in the

21 On this point see I. Testa, La natura del riconoscimento, $189 \mathrm{ff}$. 
voice it raises its singularity as such into the air and renders it universal in an untroubled and unbroken way, just as in hearing it perceives this very communication. [...] The voice as active hearing and hearing as perceiving voice are that in which the individual's sensation turns back to itself and constitutes itself as an absolute universal. The individual becomes as such immediately another to itself, and what it becomes, its simple voice, breaks itself: it hears what it says; the voice reflects itself in itself insofar as it realizes itself in another2 ${ }^{22}$

According to Hegel the voice thus has an expressive function inasmuch as it expresses the singularity of the organism in the transparent medium of sound. Moreover, the voice is communicative since it transmits the expression of the organism and as such is produced in order to be heard. Thus the voice elevates the individual to the universal of social communication. This universalizing function consists in objectivating interiority and in making it perceivable by every other natural animal endowed with the appropriate sense of hearing. At the same time, the individual which hears itself emitting its own voice, refers to itself: it has a feeling of itself as something objectivized in the sound. Here Hegel's argument reproduces an idea of Herder that was later developed by Gehlen and Mead. Mead, in particular, pointed out that vocal gestures, having the quality of affecting both the agent and its interaction partners in the same way at the same moment, are a natural evolutionary precondition for the emergence of consciousness of one's own ${ }^{23}$. In the same sense Hegel writes that "the individual becomes as such immediately another to itself". By the means of the vocal gesture one can induce the other's reaction in oneself, since one hears one's own utterance as coming from the outside -just like any other hearer.

In the voice is thus expressively posited the already given unity between self-relation and relation to the other. As Hegel writes, "the voice reflects itself in itself insofar as it realizes itself in another". The animal voice, encompassing the relation to the other and the relation to itself as another, is both a universalizing and an individualizing act, since it is an act of

22 "der Sinn des Tones als eines solchen ist diese einfache Unendlichkeit, in welcher das Tier dies, daß es allgemeiner Sinn ist, aller Besonderheit desselben entgegensetzt und in der Stimme seine Einzelnheit als solche in die Luft erhebt und ungetrübt und ungebrochen allgemein macht, absolut mitteilt, so wie es im Hören eben diese Mitteilung empfängt. [...] Die Stimme als das tätige Gehör und das Gehör als die Empfangende Stimme sind es, worin die Empfindung des Individuums sich in sich zurücknimmt und sich als absolut Allgemeines konstituiert. Das Individuum wird sich als solches unmittelbar ein anderes, und die es wird, seine einfache Stimme, bricht sich; es hört das, was es spricht; sie reflektiert sich in sich selbst, indem sie in einem andern sich realisiert." (GW6, Fragment 13, 239 and 239n.).

23 See G.H. Mead, "The Mechanism of Social Consciousness", in his Selected Writings, 134-141 (Indianapolis: Library of the Liberal Arts, 1964). On this aspect of Mead's social psychology see A. Honneth, The struggle for recognition, 73-74. 
social expressive self-identification. It is in the animal voice - which is not yet semantic and discursive language - that natural structures of recognition begin to become reflexive.

\section{The objectivized and rational recognition of procreation}

Let us come to the last step of this reconstruction, concerning the form of recognition that manifests itself through procreation and that constitutes the first objectivized structure of reason.

Hegel analyzes the voice not only as a theoretical determination but also in relation to the role it plays within the double cycle of self-preservation and of sexual reproduction. The expressive and communicative function of the voice is, in fact, linked to the development of this cycle and cannot be understood separately from it. In this sense, the animal voice presents itself first of all as a sexual appeal of the organism, and thereafter also as a cry of alarm of the animal in danger, or else as the moan of an animal approaching death. Concerning the first aspect, the expressive function of the voice is strictly bound up with sexual differentiation of individuals. Hegel writes:

Insofar as in the voice the singular returns absolutely to itself, and the individual expresses itself as absolutely universal, this turning back of its own entire individuality is also immediately its becoming other as this whole; its simple voice breaks itself and the individual enters the difference of sexes. In the voice species and individual, universality and infinity coincide; and in this absolutely reflected unity of the individual, the individual as a whole has become something external to itself.. ${ }^{24}$

It is with the moment of procreation that a new form of natural recognition becomes possible. Appetite was already fundamentally bound to find itself in another, in an opposite. Still the constitutive relation to the opposite was present only in a negative form. With procreation a new form of objectivation and positive intuition of oneself in another is now

24 "Indem in der Stimme das Einzelne absolut in sich zurückgeht, das Individuum sich als absolut allgemeines ausspricht, so ist dies sein Zurückgehen seiner ganzen Individualität, unmittelbar sein sich als dies Ganze Anderswerden; seine einfache Stimme bricht sich, und das Individuum tritt in die Geschlechtsdifferenz. In der Stimme fallen Gattung und Individuum, Allgemeinheit und Unendlichkeit in eins; und in dieser absoluten reflektierten Einheit der Individualität ist es sich als ganzes Individuum ein äußeres geworden" (GW6, Fragment 13, 240). 
possible. Hegel writes that "by knowing the child, the animal is the species that has become to itself" 25 .

In the child the organism can have a positive intuition of its own Gattung. It is important to stress that it is exactly here that the first, natural structure of what Hegel calls "Reason (Vernunft)" emerges:

The fact that in the child the species becomes something external for the animal, that it separates itself from it (the species), this becoming external of universality, is the highest form of rationality of which the animal is capable. ${ }^{26}$

Natural recognition, in its higher moment, is thus the natural form of the universality of reason. The structures of rationality, according to Hegel, are emergent in the natural process. In particular, rationality arises out of the recognitive structures of animal interaction, which manifest primitive, natural forms of social objectivation and of social universalization of individuals.

The universality of the Gattung assumes here the consistence of a new individual, a "middle term" that objectivizes the relation between the parents. It is precisely this recognitive and objectivizing aspect of the relation to the universal that constitutes the rational content of this moment. As the first form of this objectivation, the form of recognition linked to procreation is the natural antecedent of the spiritual and institutional objectivation in which reason consists.

This is nevertheless still a defective form, since here the individual is not really preserved as such. Furthermore, after reproduction, the individual falls back again into the obscurity of the Gattung. In their child the parents intuit their own annihilation and the exhaustion of their vital cycle rather than the preservation of their own individuality. The action of the individual manifests itself as an action of the Gattung - a natural form of the cunning of reason, which makes use of the individual and of its appetites to perpetuate itself.

Here we are faced with the limits of animal's individuation and of the natural form of the universality of reason. In nature the universal does not subsist for itself, unlike in the spiritual domain where the universal is objectified in a series of habits and institutions and is

25 “im Erkennen des Kinds ist das Tier sich gewordne Gattung” (GW6, Fragment 14, 244).

26 "Dies, daß dem Tier die Gattung im Kinde selbst ein Äußeres wird, daß es sich von ihr unterscheidet, dies Äußerlichwerden der Allgemeinheit ist die höchste Form Vernünftigkeit, deren das Tier fähig ist” (GW6, Fragment 14, 244.). 
as such the condition of true individuality. Furthermore, even though the individual's longing for recognition is emergent in nature, individuality is nevertheless not recognized as such in the universal of the species and remains a fragile, evanescent moment.

Natural recognition and objectivation mark the beginning of a process of individuation through universalization that accomplishes itself only when social universalization manifests itself as institutional socialization of individuals. Still, the higher, more complex forms of "spiritual" universalization are further developments of the natural process and continue to presuppose natural forms of social recognition and to constantly reshape them in always new forms of second natural habits and customs ${ }^{27}$.

From here on Hegel comes to the final stage of this process, i.e. to the determinations of "sickness" and "death". The expressive, recognitive dimensions linked to these moments of the analysis of the animal organism should be noted. The natural self's longing to be recognized for its own individuality is, in fact, the driving force behind this process. Sickness is precisely a moment in which the animal individual strives to free itself from the organic system and to affirm its own individuality as a universal. But this destruction - in which sickness consists - of the process of differentiation that is the proper element of life, is bound to death: "With sickness, the animal transgresses the limits of its own nature: but the sickness of the animal is the becoming of spirit" ${ }^{28}$. Death is here understood as the constitutive sickness of the animal individual. The individual, insofar as it distinguishes

27 According to Honneth (Struggle for Recognition, chap. 3), the point of departure of Hegel's theory of recognition was in the System der Sittlichkeit "natural ethical life (natürliche Sittlichkeit)", that is an Aristotelian system of primary practical intersubjectivity.Later, and indeed already in his 1803-4 Philosophy of Spirit, Hegel abandoned this communicational framework in favour of a metaphysical and monological model of spirit. Honneth's interpretation of the Jena writings does not take into account Hegel's analysis of natural recognition at the animal level - an account that remains valid also when Hegel distantiates himself from Aristotelian substantialism and introduces the notion of spirit. This is why Honneth is forced to understand Hegel's introduction of the notion of spirit as a metaphysical move that breaks up with natural interaction.If one realizes the role that recognition already plays within nature, then the naturalistic foundation of recognition that Honneth seeks in Mead can be retraced in Hegel himself, and the notion of spirit can be read in a nonmonological and non anti-naturalistic way, i.e. as something emerging from natural interaction. The reprise of Hegelian spirit along these lines could offer also an interesting strategy to renew the program of an anthropological and naturalist reading of social agency, such as the young Honneth developed with H. Joas (see A. Honneth \& H. Joas, Soziales Handeln und menschliche Natur, Frankfurt am Main: Campus Verlag, 1980) and later progressively abandoned in favor of a normatively oriented approach. For an immanent criticism of the shortcomings of Honneth's later abandonment of a more naturalist and materialist oriented theory of interaction see JP. Deranty, "The Loss of Nature in Axel Honneth's Theory of Recognition“, Critical Horizons, 6, 1 (2005), 153-181.

28 "mit der Krankheit überschreitet das Tier die Grenze seiner Natur; aber die Krankheit des Tiers ist das Werden des Geistes" (GW6, Fragment 15, 259-260). 
itself from the species and differentiates itself as a singular form of life, cannot endure and is destined to die, to be reabsorbed in the species. That is why with sickness and death the animal "transgresses the limits of its nature". On the one hand, with death the bounds of the natural individuality of his life are annihilated. On the other hand, it is just in the process of sickness and death that the animal can assert its longing for a higher form of individuality. For this reason sickness and death are an important moment of the emergence of spiritual structures from nature.

It is important to note that the phenomena of sickness and death are also accompanied by the voice in Hegel's description. In the death cry the voice strives to save, in the universal medium of the voice, the disappearing singularity. The death cry gives expression, precisely in the moment of the individual's elimination, to its longing to be recognized as such: it is for this reason that death is qualified by Hegel in his 1805-6 lessons as "the becoming of consciousness (Werden des Bewußtseins)" ${ }^{\prime 29}$.

With the moments of sexual differentiation, cerebralization, expressive voice, reproduction, sickness and death, the recognitive and social dialectical structures of reason have already manifested themselves at the natural level: the animal is nevertheless this structure only in itself, and not for itself. The union of opposites manifests itself only in the contact of bodies or in the body of the child: the opposite determination falls outside of animal consciousness and is not yet reprised in its own simple unity. This is to say that in the animal the union of opposites has not yet become the object of a reflexive knowing whose structure is itself dialectical and which will stabilize itself in institutional forms. But this reflexive knowing, which develops in human life through the recursive application to itself of the structure of Begierde $^{30}$, is only what makes explicit the fundamental structures that have already developed in the recognitive activity and emerging consciousness of the animal organism.

\section{Coda: the recognitive consciousness}

29 G.W.F. Hegel, Jenaer Systementwürfe III. Naturphilosophie und Philosophie des Geistes. R.-P. Horstmann and J.H. Trede (eds). In Gesammelte Werke, vol. 8, 172 (Hamburg: Meiner, 1976).

30 On this idea of recursive application to itself of Begierde see R.B. Brandom, "The Structure of Desire and Recognition. Self-consciousness and Self-constitution", Philosophy \& Social Criticism, 33, 1 (2007), 127-150. 
So far we have seen how in Hegel's lessons a proto-intentional self, endowed with communicative capacities and self-feeling, emerges from natural interactions. In the different steps of my reconstruction I have defended the thesis that this natural self already has a pre-reflexive form of natural recognitive consciousness, and that this form of natural recognitive consciousness is presupposed by the reflexive consciousness which will develop in institutionalized, that is spiritual, forms of life.

Recognitive social consciousness is thus a structure with which man is endowed as a natural being $^{31}$. Consciousness, as a negative structure, is first of all a form of animal life ${ }^{32}$ : according to Hegel, it is the "ideality of nature", i.e. a negative relation to nature, a relation that exists as such within nature and manifests itself at first as Begierde:

The being of consciousness in general is, to begin with - when it posits in itself the reflection that was previously ours - that it is the ideality of nature; in other words it is at first in [a] negative relation with nature, and in this negative relation it exists as tied to nature itself within this relation; the mode of its existence is not a particular [or] a singular aspect of nature, but a universal [moment] of nature, an element of it. ${ }^{33}$

31 The boot-strapping model of spirit as a radical historical and artificial achievement is supported by the assumption that recognition does not involve any subject exercising some sort of faculty or the appeal to the actualization of some sort of human potential (see R. Pippin, "Hegelian Sociality: Recognitive Status", 190-194, 204; see also T. Pinkard, German Philosophy 1760-1860. The Legacy of Idealism, 280, Cambridge: Cambridge University Press, 2002). Since the present reconstruction of recognition should give some reasons not to make such an assumption, then some consequences may arise also for the way we are to conceive the very notion of spirit as something that does not float free of our naturalness.

32 Analyzing the philosophy of subjective spirit in the Encyclopedia, H. Hikäheimo has very well shown that, according to what he calls Hegel's "unofficial account", there is a form of "primitive intentionality" - i.e. of "consciousness" - that animals share with uncultivated humans (“Animal Consciousness in Hegel's Philosophy of Subjective Spirit”, HegelJahrbuch, 2011, forthcoming). In another paper Ikäheimo has argued that pre-normative recognitive attitudes may be constitutive - and distinctive - of the animal nature of human beings, insofar as they seem to play a role in the way normal human infants engage in the pre-linguistic communicative practice of pointing things to others (as described by Michael Tomasello). If one reads this in the light of the Hegelian theory of natural interaction I have tried to unpack in the Jena writings, then even the form of primitive intentionality that Hegel ascribes to animals could be characterized in recognitive terms. This could offer a strategy to read in continuity such a form of animal primitive intentionality and the recognitive capacities that seem to be constitutive of the human pre-linguistic practice of pointing.

33 "sein Sein überhaupt ist zuerst, wie es in sich selbst die Reflexion setzt, die bisher die unsrige war, daß es die Idealität der Natur ist, oder ist zuerst in negativer Beziehung auf die Natur; und in dieser negativen Beziehung existiert es al bezogen auf die Natur selbst innerhalb derselben, und die Weise seiner Existenz ist nicht eine Besonderheit, eine Einzelnheit der Natur, sondern ein Allgemeines der Natur, ein Element der Natur" (GW6, Fragment 18, 276, published in English in G.W.F. Hegel, System of Ethical Life (1802-3) and First Philosophy of Spirit (Part III of the System of Speculative Philosophy 1803/04), 214-215. 
I suggest that the further developments of reflexive consciousness can be interpreted as reorganizations and institutional stabilizations of that recognitive consciousness, which had already emerged within natural life, but develops here at a more complex level. This interpretive reconstruction of Hegelian texts may also have systematic relevance, inasmuch as it can help us to develop a theoretical model which could be of use today in helping us to face up to some problems that arise within contemporary theories of recognition ${ }^{34}$.

As I argued at the very beginning of this article, once contemporary theories situate recognition exclusively within the historical sphere, they end up being either circular, or introducing recognition merely as a self-explicating presupposition. This way the deeper, embodied structure of recognition is lost, and the phenomenon tends to be reduced to a historically nuanced notion of rational normativity. This is not only unfair to Hegel's notion of spirit - which was much deeper than that - but leads also to a kind of strong antinaturalistic social ontology 35 . But such a consequence is not inherent in the very notion of recognition - as if assuming recognition as the basic structure of the social world would lead us inevitably to understand sociality as a disembodied, free-floating realm. Rather it is due to a peculiar understanding of it: an understanding of recognition we are not obliged to commit ourselves to. In fact recognition - and here an exegetical reading of Hegel can be of help - could be (better) reconstructed as a phenomenon emerging from nature and somehow

34 For a development of this thesis see I. Testa, "Second Nature and Recognition. Hegel and the Social Space", Critical Horizons, 10, 3 (2009), 341-370.

35 A convincing critical analysis of the main dogmas - anthropological discontinuity, strong constructivism, opposition between social normativity and naturalness - of contemporary anti-naturalism in social ontology and social theory has been developed by S. Haber in Critique de l'antinaturalisme. Études sur Foucault, Butler, Habermas (Paris: PUF, 2006). It is interesting to note that similar presuppositions are shared by contemporary readings of Hegel that stress the autonomy of objective spirit from natural processes and understand recognition in merely normative terms. Along the lines of the argument made in this paper, J.P. Deranty has shown how current pragmatist interpretations of Hegel's spirit understand it in a merely rationalistic, disembodied way, because they disassemble recognition form its genetic function (J.P. Deranty, "Rationality, Autonomy and the Social Bond. Models of Hegelian Recognition and their Implications for Social and Political Theory", Philosophy Today, Spring 2011, 3-11)). I think that the appreciation of the naturalistic strands of the Hegelian Anthropology (see I. Testa, "Hegel's Naturalism, or Soul and Body in the Encyclopedia", forthcoming in D. Stern (ed.), Essays on Hegel's Philosophy of Subjective Spirit: Albany, NY: SUNY) as well as the appreciation of the nexus between nature, recognition and second nature (see I. Testa, "Selbstbewusstsein und zweite Natur", in Hegels Phänomenologie des Geistes, K. Vieweg \& W. Welsch (eds), 286-307, Frankfurt am Main: Suhrkamp, 2008) could be the best way to vindicate an embodied Hegelian account of sociality and human agency. Along the lines of a materialist appropriation of Hegel see also in this collection E. Renault's worthwhile contribution to a reading of Hegel's pragmatism in some continuity with Dewey's naturalism (“The Naturalist Side of Hegel’s Pragmatism”). 
having a foothold in it. In this way the role of recognition as the basic structure of the social and historical world (of spirit) would not be denied, but rather reinforced, since we could break away from the hyper-rationalistic and anti-naturalistic consequences of the selfexplicating, bootstrapping model of recognition and of sociality.

\section{References}

Breidbach, O. 1982. Das Organische in Hegels Denken. Studien zur Naturphilosophie und Biologie um 1800. Würzburg: Königshausen \& Neumann.

Braidbach, O. 1998. "Das Organische in Hegels Jenaer Naturphilosophie". In Hegels Jenaer Naturphilosophie, K. Vieweg (ed), 309-318. München: Fink.

Brandom, R.B. 2007. "The Structure of Desire and Recognition. Self-consciousness and Selfconstitution". Philosophy \& Social Criticism, 33 (1): 127-150.

Deranty, J.P. 2005, “The Loss of Nature in Axel Honneth's Theory of Recognition“. Critical Horizons, 6 (1): 153-181.

Deranty, J.P. 2011. "Rationality, Autonomy and the Social Bond. Models of Hegelian Recognition and their Implications for Social and Political Theory". Philosophy Today, 3-11.

Engelhardt, D. von 1986. “Die biologische Wissenschaften in Hegels Naturphilosophie". In Hegels Philosophie der Natur, R.-P. Horstmann \& M.J. Petry (eds), 121-137. Stuttgart Bad Cannstatt: Frommann-Holzboog.

Fraser, N. 1995. "From Redistribution to Recognition? Dilemmas of Justice in a 'Postsocialist Age"”. New Left Review, 212 (July-August 1995): 68-93.

Haber, S. 2006. Critique de l'antinaturalisme. Études sur Foucault, Butler, Habermas (Paris: PUF). 
Harris, H.S. 1983. Hegel's Development II. Night Thoughts (Jena 1801-1806). Oxford: Clarendon Press.

Hegel, G.W.F. 1932. Jenenser Realphilosophie, I. Die Vorlesungen von 1803/4, J. Hoffmeister (ed). Leipzig.

Hegel, G.W.F. 1968. Differenz. In Kritische Schriften, H. Buchner \& O. Pöggeler (eds). In Gesammelte Werke, vol. 4. Hamburg: Meiner. Published in English as The difference between Fichte's and Schelling's system of philosophy, H. S. Harris \& W. Cerf (trans.) (Albany: Suny, 1977).

Hegel, G.W.F. 1975. Jenaer Systementwürfe I. Das System der spekulativen Philosophie, K. Düsing \& H. Kimmerle (eds). In Gesammelte Werke, vol. 6. Hamburg: Meiner.

Hegel, G.W.F. 1976. Jenaer Systementwürfe III. Naturphilosophie und Philosophie des Geistes, R.-P. Horstmann and J.H. Trede (eds). In Gesammelte Werke, vol. 8. Hamburg: Meiner.

Hegel, G.W.F. 1979. System of Ethical Life (1802-3) and First Philosophy of Spirit (Part III of the System of Speculative Philosophy 1803/04), H.S. Harris and T.M. Know (eds. and trans.). Albany: Suny.

Honneth, A. \& Joas H. 1980. Soziales Handeln und menschliche Natur. Frankfurt am Main: Campus Verlag.

Honneth, A. 1992. Kampf um Anerkennung: Zur moralischen Grammatik sozialer Konflikte. Frankfurt: Suhrkamp. Published in English as The Struggle for Recognition: The Moral Grammar of Social Conflicts, J. Anderson (trans.) (Cambridge: Polity Press, 1995). 
Ikäheimo, H. 2011. “Animal Consciousness in Hegel's Philosophy of Subjective Spirit”. HegelJahrbuch. Forthcoming.

Ikäheimo, H. 2010. "Is 'recognition' in the sense of intrinsic motivational altruism necessary for pre-linguistic communicative pointing?". In W. Christensen, E. Schier, and J. Sutton (Eds.), ASCS09: Proceedings of the 9th Conference of the Australasian Society for Cognitive Science (pp. 145-153). Sydney: Macquarie Centre for Cognitive Science.

Illetterati, L. 1995. "Vita e organismo nella filosofia della natura di Hegel". In Filosofia e scienze filosofiche nell'Enciclopedia' hegeliana del 1817, F. Chiereghin (ed), 327-427. Trento: Verifiche.

Kimmerle, H. 1980. "Hegels Naturphilosophie in Jena”. In Hegel in Jena, D. Henrich \& K. Düsing (eds), 207-215. Bonn: Bouvier.

Mead, G.H. 1964. "The Mechanism of Social Consciousness". In his Selected Writings. Indianapolis: Library of the Liberal Arts.

Neuser, W. 2004. "Hegels Naturphilosophie der Jenaer Zeit und ihre Bedeutung für die Systemkonzeption". In Die Eigenbedeutung der Jenaer Systemkonzeptionen Hegels, H. Kimmerle (ed), 89-98. Berlin: Akademie Verlag.

Pippin, R. B. 2008. "Hegelian Sociality: Recognitive Status". In his Hegel's Practical Philosophy. Rational Agency as Practical Life, 189-209. Cambridge: Cambridge University Press.

Pinkard, T. 1994. Hegel's Phenomenology: The Sociality of Reason. Cambridge: Cambridge University Press.

Pinkard, T. 2002. German Philosophy 1760-1860. The Legacy of Idealism. Cambridge: Cambridge University Press. 
Renault, E. 2009. "Les transformations de l'idée de Naturphilosophie à Ièna (1801-6)". Paper given at the conference "Hegel et les Esquisses de Système d'Ièna", École Normale Supérieure de Lyon, 13 Novembre (manuscript, forthcoming in the conference procedings).

Renault, E. 2012. “The Naturalist Side of Hegel's Pragmatism”, Critical Horizons.

Taylor, Ch., Guttmann, A. (eds.) 1992. Multiculturalism and the 'Politics of Recognition (Princeton: Princeton University Press).

Rühling, F. 1998. “Anorganische Natur als Subjekt”. In Hegels Jenaer Naturphilosophie, 359366.

Schlösser, U. 2004. "Natur und Geist oder Leib und Seele? Eine Perspektive auf Hegels Systemansatz in den "Jenaer Systementwürfen I". In Die Eigenbedeutung der Jenaer Systemkonzeptionen Hegels, 117-133.

Testa, I. 2008. "Selbstbewusstsein und zweite Natur". In Hegels Phänomenologie des Geistes, K. Vieweg \& W. Welsch (eds), 286-307. Frankfurt am main: Suhrkamp.

Testa, I., 2008. "Hegel's Naturalism, or Soul and Body in the Encyclopedia". Paper given at the 20th Biennial Meeting of the Hegel Society of America, University of South Carolina (October 24-26, 2008). Forthcoming in: D. Stern (ed.), Essays on Hegel's Philosophy of Subjective Spirit, Albany (NY): SUNY.

Testa, I. 2009. "Second Nature and Recognition. Hegel and the Social Space", Critical Horizons, 10 (3): 341-370

Testa, I. 2010. La natura del riconoscimento. Riconoscimento naturale e autocoscienza sociale in Hegel. Milano: Mimesis. 
Tuschling, B. 1998. "Natur und Geist im Systementwurf I". In Hegels Jenaer Naturphilosophie, 71-83. 